\title{
Clinicopathologic features of ameloblastoma in southern Brazil: A 55-year single-center analysis
}

Ana Luisa Homem de Carvalho ${ }^{\mathrm{a}}$, Manoela Domingues Martins ${ }^{\mathrm{b}}$, Francinne Miranda da Rosa ${ }^{\mathrm{b}}$, Annemarie Saudades ${ }^{b}$, Manoel Sant ${ }^{\prime}$ Ana Filho ${ }^{b}$

\section{ABSTRACT}

Objective: Ameloblastoma is a benign odontogenic tumor (OT) originating from the proliferation of odontogenic epithelium without involvement of the mesenchymal tissue. The aims of the present study were to perform a retrospective analysis of ameloblastoma, compare the findings with those described in previous studies and outline the epidemiological profile of this type of tumor in southern Brazilian population.

Methods: Cases of ameloblastoma were retrieved between 1954 and 2009 from a single center and analyzed for age, gender, ethnic, primary site and histological type. Cases were classified according to the 2005 WHO classification of OTs.

Results: Descriptive statistical analysis of the data was performed, with the determination of the frequency of the categorical variables. Eighty-nine cases of ameloblastoma were found: 78 cases of solid tumor (88.6\%), two cases of desmoplastic tumor (2.2\%) and nine cases of the unicystic tumor (10.2\%). There was a predominance of the female gender (58.4\%) and Caucasian ethnicity (62.9\%). Most ameloblastomas were located in the mandible (78.6\%) and $40.2 \%$ occurred prior to the third decade of life.

Conclusion: The present findings are in agreement with those reported in previous studies carried out in other states of Brazil and support that notion that there may be a geographical influence on the profile of patients affected by ameloblastoma.

Key words: Odontogenic tumors; Ameloblastoma; Epidemiology

\section{Aspectos clinico-patológicos de ameloblastomas no sul do Brasil: 55 anos de uma única Instituição}

\section{RESUMO}

Introdução: Ameloblastoma é uma neoplasia odontogênica benigna (NOB) que se origina da proliferação do epitélio odontogênico sem envolvimento do mesênquima. Os objetivos do presente estudo foram realizar uma análise retrospectiva do ameloblastoma, comparar os resultados com os descritos em estudos anteriores e traçar o perfil epidemiológico deste tipo de tumor na população do sul do Brasil.

Metodologia: Casos de ameloblastoma diagnosticados entre 1954 e 2009 em um único centro foram analisados quanto á idade, sexo, etnia, localização e tipo histológico. Os casos foram classificados de acordo com a classificação da OMS de 2005 de NOBs.

Resultados: Foi realizada análise estatística descritiva dos dados com a determinação da freqüência das variáveis categóricas. Oitenta e nove casos de ameloblastomas foram diagnosticados: 78 casos corresponderam ao tipo sólido (88.6\%), dois casos ao tipo desmoplásico (2.2\%) e nove casos ao tipo unicístico (10.2\%). Houve predomínio pelo gênero feminine (58.4\%) e de etnia branca (62.9\%). A maioria localizou-se na mandíbula (78.6\%) e $40.2 \%$ ocorreram preferencialmente na terceira década de vida.

Conclusão: Nossos achados estão de acordo com os achados realizados em outros estados do Brasil. Isto mostra que pode ocorrer uma influência geográfica sobre o perfil dos pacientes acometidos por ameloblastoma.

Palavras-chave: Tumores odontogênicos; Ameloblastoma; Epidemiologia a Oral Pathology,School of Dentistry, Pontifical Catholic University of Rio Grande do Sul (PUCRS), Porto Alegre, Brazil

b Oral Pathology Department, School of Dentistry, Universidade Federal do Rio Grande do Sul, Porto Alegre, Brazil 


\section{INTRODUCTION}

According to the World Health Organization [1], ameloblastoma is a benign odontogenic tumor originating from the proliferation of odontogenic epithelium without involvement of the mesenchymal tissue. It accounts for $1 \%$ of all tumors of the maxilla as well as $11 \%$ of all odontogenic tumors. The slow, painless growth of this tumor often results in a late diagnosis [2]. Although benign, ameloblastoma is locally invasive and therefore surgery with a margin of safety is the treatment of choice, which results in considerable mutilation in many cases $[3,4]$. However, the mechanism for this invasive behavior remains unknown $[1,5,6]$.

From the clinical-radiological standpoint, ameloblastoma is classified as solid or multicystic (70 to $80 \%$ of cases), unicystic (13\%), peripheral or extraosseous (2 to $10 \%$ ) [1]. Clinically, it is most commonly found in the posterior region of the mandible ( $70 \%$ of cases) $[1,4,7,8]$. Histologically, ameloblastoma is classified as solid, desmoplastic or unicystic [1]. The solid types are subdivided into follicular, plexiform (which are the most common), acanthomatous, granular cell or basal cell [1]. More than one histological types can be found in the same tumor [1,9]. However, there is little evidence that these histological types have any significance regarding clinical behavior and prognosis. The unicystic variant generally affects younger patients (second decade of life). This form is considered less invasive and consequently associated to more conservative treatment, a more favorable prognosis and a lesser incidence of recurrence $[4,7,8]$.
There is no consensus in the literature on the most appropriate form of treatment for the different types of ameloblastoma. Conservative treatment consists of enucleation and curettage, followed by cyrotherapy, whereas more radical treatment involves marginal resection of the affected segment or mandibulectomy/maxillectomy. Due to its less aggressive behavior, conservative treatment is recommended for a unicystic ameloblastoma [2].

Studies have been published on the profile of patients with ameloblastoma and it is reported that geographic variations may exert an influence on epidemiological data regarding this tumor in different populations [5,10-18] (Table 1). The aims of the present study were to perform a retrospective analysis of cases of ameloblastoma, compare the findings with those described in previous studies and outline the epidemiological profile of this type of tumor in the Brazilian population.

\section{METHODS}

The present retrospective study received approval from the Human Research Ethics Committee of the Universidade Federal do Rio Grande do Sul (UFRGS, Brazil).

All records of histopathological findings of the Histopathology Laboratory of the UFRGS School of Dentistry (southern Brazil) between 1954 and 2009 were reviewed for the identification of cases with a diagnosis of ameloblastoma. Slides stained with hematoxylin \& eosin were examined under an optical microscope for the confirmation of the diagnosis and the findings were

Table 1. Summary of papers with analysis of clinical-demographic data on ameloblastoma.

\begin{tabular}{|c|c|c|c|c|c|c|c|}
\hline Authors/year of publication & Study location & Sample size & Period analyzed & Gender & Anatomic site & Ethnic group & Age \\
\hline Chidzonga et al., 1996 & Zimbabwe & 117 cases & 1982 to 1991 & Men (53\%) & $\begin{array}{c}\text { Mandible } \\
(95.7 \%)\end{array}$ & - & $\begin{array}{c}\text { Mean age: } \\
30 \text { years }\end{array}$ \\
\hline Mosqueda-Taylor et al., 1997 & Mexico & 80 cases & 1960 to 1996 & Women (55.4\%) & $\begin{array}{c}\text { Mandible } \\
(82.4 \%)\end{array}$ & - & 11 to 79 years \\
\hline Junquera et al., 2003 & Spain & 22 cases & 1975 to 2000 & Women (59\%) & $\begin{array}{c}\text { Mandible } \\
(100 \%)\end{array}$ & & 22 to 72 years \\
\hline Fernandes et al., 2005 & Brazil & 154 cases & 1954 to 2004 & Women (54.5\%) & $\begin{array}{c}\text { Mandible } \\
(85 \%)\end{array}$ & - & $\begin{array}{l}\text { Mean age: } \\
27.7 \text { years }\end{array}$ \\
\hline Ledesma-Montes et al., 2007 & $\begin{array}{c}\text { Mexico and } \\
\text { Guatemala }\end{array}$ & 163 cases & 1959 to 2000 & Men (52.8\%) & $\begin{array}{c}\text { Mandible } \\
(86.4 \%)\end{array}$ & - & $\begin{array}{l}\text { Mean age: } \\
31.7 \text { years }\end{array}$ \\
\hline Adeline et al., 2008 & Kenya & 184 cases & 1995 to 2005 & Women (55.4\%) & $\begin{array}{c}\text { Mandible } \\
(93.5 \%)\end{array}$ & - & $\begin{array}{l}\text { Mean age: } \\
30.2 \text { years }\end{array}$ \\
\hline Tawfik et al., 2010 & Egypt & 34 cases & 1993 to 2008 & Men (67.65\%) & $\begin{array}{c}\text { Mandible } \\
(94.4 \%)\end{array}$ & - & $\begin{array}{l}\text { Mean age: } \\
34.5 \text { years }\end{array}$ \\
\hline Fregnani et al., 2010 & Brazil & 121 cases & 1953 to 2003 & Women (53\%) & $\begin{array}{c}\text { Mandible } \\
(80 \%)\end{array}$ & $\begin{array}{c}\text { Caucasian } \\
(72 \%)\end{array}$ & $\begin{array}{c}18 \text { to } 32 \text { years } \\
(41.3 \%)\end{array}$ \\
\hline Fulco et al., 2010 & Brazil & 54 cases & Not informed & $\begin{array}{c}\text { Women (50\%) } \\
\text { Men (50\%) }\end{array}$ & $\begin{array}{c}\text { Mandible } \\
(98.1 \%)\end{array}$ & - & $\begin{array}{l}\text { Mean age: } \\
38.3 \text { years }\end{array}$ \\
\hline Krishnapillai, Angadi, 2010 & India & 73 cases & 1989 to 2007 & Men (56.1\%) & $\begin{array}{c}\text { Mandible } \\
(91.8 \%)\end{array}$ & - & 10 to 78 years \\
\hline Present study & Brazil & 89 cases & 1954 to 2009 & Women (58.4\%) & $\begin{array}{c}\text { Mandible } \\
(78.6 \%)\end{array}$ & $\begin{array}{c}\text { Caucasian } \\
(62.9 \%)\end{array}$ & $\begin{array}{c}10 \text { to } 29 \text { years } \\
(40.2 \%)\end{array}$ \\
\hline
\end{tabular}


classified based on the criteria defined by the WHO [1] as solid ameloblastoma (subtypes: follicular, plexiform, acanthomatous, granular cell and basal cell), desmoplastic ameloblastoma or unicystic ameloblatoma. The following variables were also analyzed: gender, age, ethnic background, anatomic site and histological type. Among the 96 cases with a histopathological diagnosis of ameloblastoma, 89 contained information on these variables and were included in the present study.

A database was built using the Excel ${ }^{\circledR}$ program, followed by statistical analysis using the Statistical Package for Social Sciences ${ }^{\circledR}$ (version 13.0). The level of significance was set to $5 \%$. Categorical variables were tabulated as follows: gender (male and female), ethnic background (Caucasian, African descent, other ethnicity and not informed), anatomic site (mandible, maxilla and not informed) and histological type (follicular, plexiform, acanthomatous, granular cell and basal cell). The quantitative variable age was categorized in decades of life to facilitate the analysis and comprehension of the data. Descriptive statistical analysis was performed for the determination of the frequencies of the categorical variables studied.

\section{RESULTS}

A total of 32,035 tumors were diagnosed at the UFRGS Oral Histopathology Laboratory between 1954 and 2009, 89 of which were cases of ameloblastoma, accounting for $0.27 \%$ of the diagnoses. Descriptive analysis was performed based on the histopathological diagnosis, patient characteristics and anatomical location (Table 2). Among the 89 cases of ameloblastoma, 78 were solid tumors $(88.6 \%)$, two were desmoplastic tumors $(2.2 \%)$ and nine were unicystic tumors $(10.2 \%)$.

Among the solid tumors, there was a predominance of the female gender $(56.0 \%)$ and Caucasian ethnicity $(66.7 \%)$; most were located in the mandible $(76.9 \%)$ and $40.2 \%$ occurred prior to the third decade of life. Regarding the histological findings, the follicular form was the most prevalent (34 cases; $43.68 \%$ ), followed by the plexiform (29 cases; $37.2 \%)$, acanthomatous ( 8 cases; $10.3 \%$ ) and basal cell ( 5 cases; $6.3 \%$ ) types. No cases of granular cell ameloblastoma were diagnosed. Two cases were classified as "not identified" $(2.6 \%)$ and corresponded to cases with more than one histological pattern on the same slide. The cases of desmoplastic ameloblastoma occurred in the mandible of Caucasian women in the $5^{\text {th }}$ decade of life (one of these cases had no information on the ethnic background or age of the patient). Unicystic ameloblastoma was more prevalent in the female gender $(66.7 \%)$, affected individuals of Caucasian and African descent equally (33.3\%), was located predominantly in the mandible $(88.9 \%)$ and occurred mostly between the third and sixth decades of life $(77.7 \%)$ (Table 2).

Table 2. Distribution of ameloblastomas according to gender, ethnic background, anatomic site and age group; Porto Alegre, Rio Grande do Sul, Brazil, 2010

\begin{tabular}{|c|c|c|c|c|c|}
\hline & Variable & $\begin{array}{l}\text { Solid ameloblastoma } \\
\qquad(N=78) 88.6 \%\end{array}$ & $\begin{array}{l}\text { Desmoplastic ameloblastoma } \\
\qquad(n=02) 2.2 \%\end{array}$ & $\begin{array}{c}\text { Unicystic ameloblastoma } \\
(\mathrm{N}=09) 10.2 \%\end{array}$ & $\begin{array}{c}\text { Total } \\
(\mathrm{N}=89) 100 \%\end{array}$ \\
\hline \multirow[t]{3}{*}{ Gender } & Male & 31 (39.7\%) & $0(0 \%)$ & 03 (33.3\%) & 34 (38.2\%) \\
\hline & Female & $44(56.4 \%)$ & 02 (100\%) & 06 (66.7\%) & 52 (58.4\%) \\
\hline & Not informed & 03 (3.8\%) & 0 (\%) & $0(0 \%)$ & 03 (3.4\%) \\
\hline \multirow[t]{9}{*}{ Age } & 10 to 19 years & $10(12.8 \%)$ & $0(0 \%)$ & 03 (33.3\%) & $13(14.6 \%)$ \\
\hline & 20 to 29 years & 22 (28.2\%) & $0(0 \%)$ & $01(11.1 \%)$ & $23(25.6 \%)$ \\
\hline & 30 to 39 years & 15 (19.2\%) & $0(0 \%)$ & $0(0 \%)$ & 15 (16.8\%) \\
\hline & 40 to 49 years & $10(12.8 \%)$ & $01(50 \%)$ & $0(0 \%)$ & $11(12.3 \%)$ \\
\hline & 50 to 59 years & 02 (2.6\%) & $0(0 \%)$ & 03 (33.3\%) & 05 (5.6\%) \\
\hline & 60 to 69 years & 03 (3.8\%) & $0(0 \%)$ & $0(0 \%)$ & 03 (3.8\%) \\
\hline & 70 to 79 years & 05 (6.4\%) & $0(0 \%)$ & $0(0 \%)$ & 05 (5.6\%) \\
\hline & 80 to 89 years & 01 (1.3\%) & $0(0 \%)$ & $0(0 \%)$ & $01(1.1 \%)$ \\
\hline & Not informed & $10(12.8 \%)$ & 01 (50\%) & 2 (22.2\%) & $13(14.6 \%)$ \\
\hline \multirow[t]{4}{*}{ Ethnicity } & Caucasian & $52(66.7 \%)$ & $01(50 \%)$ & 03 (33.3\%) & 56 (62.9\%) \\
\hline & African descent & $10(12.8 \%)$ & $0(0 \%)$ & 03 (33.3\%) & $13(14.6 \%)$ \\
\hline & Other ethnicity & 03 (3.8\%) & $0(0 \%)$ & $01(11.1 \%)$ & 04 (4.5\%) \\
\hline & Not informed & $13(16.7 \%)$ & 01 (50\%) & 02 (22.2\%) & $16(18.0 \%)$ \\
\hline \multirow[t]{4}{*}{ Site } & Mandible & 60 (76.9\%) & 02 (100\%) & 08 (88.9\%) & 70 (78.6\%) \\
\hline & Maxilla & 07 (9\%) & $0(0 \%)$ & $0(0 \%)$ & 07 (7.8\%) \\
\hline & Extraosseous & 02 (2.6\%) & $0(0 \%)$ & $0(0 \%)$ & 02 (2.2\%) \\
\hline & Not informed & 09 (11.6\%) & $0(0 \%)$ & $01(11.1 \%)$ & $10(11.23 \%)$ \\
\hline
\end{tabular}




\section{DISCUSSION}

The incidence of odontogenic tumors exhibits considerable variation in epidemiological studies carried out in different countries [5,10-18]. Such variations may be explained by geographic, ethnic and socioeconomic factors [16] and the large number of reactive/inflammatory tumors submitted to histopathological analysis in North American countries, which does not occur in Latin American countries [11].

Ameloblastoma is the most prevalent odontogenic tumor in studies carried out in Brazil $(45.2 \%$ to $67 \%$ of cases) $[12,16]$, China (58.6 to $59.4 \%$ ) [20,21], Nigeria $(58.5 \%)$ [22] and Egypt (41.5\%) [14]. However, a number of investigations report ameloblastoma to be the second most prevalent form of odontogenic tumor, such as studies carried out in Canada (17.8\% of cases) [22], Mexico (23.7\%) [10] and Brazil [11]. This difference may be explained by the fact that some studies do not include odontoma, which increases the relative frequency of ameloblastoma [16].

In the present study, ameloblastoma accounted for $0.27 \%$ of all tumors analyzed at the UFRGS Oral Histopathology Laboratory between 1954 and 2009. This frequency is smaller than rates reported in a Latin American population [13] and a previous Brazilian investigation [12], which describe a frequency of $0.8 \%$ and $0.5 \%$, respectively. It should be stressed that these greater frequencies were due to the fact that the studies cited used both laboratory findings and data from hospitals that received patients sent for treatment with a previous diagnosis of ameloblastoma.

Among the cases of ameloblastoma analyzed, 88.6\% were classified as solid, which is in agreement with findings described in the literature $[14,16,17]$, with the exception of a multicenter study carried out in Latin America, which found that solid amelobastoma only accounted for $33.7 \%$ of cases [13]. In the evaluation of the histological subtypes of solid ameloblastomas, the follicular and plexiform patterns were the most prevalent, which is in agreement with findings described in previous studies [3,14,17]. A number of authors state that there is little evidence that these histological types have any significance regarding clinical behavior and prognosis. However, such concepts remain controversial and further studies are needed to clarify this issue.

Desmoplastic ameloblastoma accounted for $2.2 \%$ of cases in the present study. This is in agreement with findings reported in previous investigations $[3,13,14,17]$, which report prevalence rates ranging from $0.5 \%$ to $5.6 \%$. Moreover, Fulco et al. [17] classified 3.7\% of cases as hybrid tumors formed by masses of desmoplastic ameloblastoma with significant areas of solid ameloblastoma.

The prevalence of unicystic ameloblastoma was $10.2 \%$ in the present investigation. Most studies report a lower prevalence rate of this type of tumor, ranging from $4 \%$ to $6 \%[3,14,16]$. The only study to report a greater prevalence rate of unicystic ameloblastoma in comparison to solid ameloblastoma was carried out by Ledesma-Montes et al. [13], in which $63.7 \%$ of cases were classified as unicystic ameloblastoma. The authors explain this high prevalence rate by the technical rigor employed in the differentiation of unicystic ameloblastoma from cases diagnosed as solid ameloblastoma.

Regarding gender, women were more affected by ameloblastoma in the present study (58.4\%). Data on gender differences vary in the literature. Some studies report an equal frequency between men and women [17]; others report a predominance of the male gender $[10,13,15,18]$ and still others report a predominance of the female gender $[5,11,12,14,16]$. These discrepancies suggest that the findings are directly proportional to the profile of the patients who seek medical-dental care in each population.

In the present study, $40.2 \%$ of the cases of ameloblastoma occurred prior to the third decade of life. The literature reports considerable variation regarding this variable. However, in a meta-analysis on ameloblastoma, Reichart et al. [3] report a median age of 34 and 24 years upon the initial diagnosis in industrialized and developing countries, respectively.

Studies addressing clinical-epidemiological data on ameloblastoma generally do not assess ethnic background, as this characteristic is strongly associated with cultural and socioeconomic factors. In the present study, ameloblastomas occurred with greater frequency among patients of Caucasian descent $(62.9 \%)$, which is in agreement with the $72 \%$ described by Fregnani et al. [16] in a study on this type of tumor in a sample of Brazilians. However, these data cannot be extrapolated to the national population, as the population of the state of Rio Grande do Sul is $82.3 \%$ Caucasian and $5.9 \%$ African descent; moreover, metropolitan Porto Alegre is $80.7 \%$ Caucasian and $8.0 \%$ African descent (IBGE, 2008) [23]. Therefore, a greater number of biopsies from Caucasian individuals are to be expected.

The mandible was the most affected anatomic site (78.6\% of cases). This finding is in agreement those reported in all epidemiological studies on ameloblastoma reviewed $[3,5,10-13,15,16,18]$, which demonstrates that the anatomic site of ameloblastomas is not associated with ethnic, culture or socioeconomic issues. However, we know of no explanation for the predominance of the mandible in cases of ameloblastoma.

Due to its retrospective nature, the present study cannot provide data on the current prevalence of ameloblastoma. However, one may affirm that the tumors studied herein were predominantly solid, located in the mandible and affected Caucasian women up to 29 years of age more. The only characteristic unanimously reported in all populations is the preferential location of ameloblastoma in the mandible, whereas the prevalence of the other characteristics varies in accordance with the demographic characteristics of each country. The present findings are in agreement with those reported in previous studies carried out in other states of Brazil and support that notion of a geographical influence on the profile of patients affected by ameloblastoma. 


\section{CONCLUSION}

The present findings are in agreement with those reported in previous studies carried out in other states of Brazil and support that notion that there may be a geographical influence on the profile of patients affected by ameloblastoma.

\section{ACKNOWLEDGMENTS}

Supported by CAPES (Coordenação de Aperfeiçoamento de Pessoal de Nível Superior): PhD scholarship.

\section{REFERENCES}

1. Sciubba JJ, Eversole LR, Slootweg PJ. WHO Pathology \& Genetics Head and Neck Tumours. 2005;6:287-9

2. Ghandhi D, Ayoub AF, Pogrel MA, MacDonald G, Brocklebank LM, Moos KF. Ameloblastoma: A Surgeon's Dilemma. J Oral Maxillofac Surg. 2006;64:1010-1014

3. Reichart PA, Philipsen HP, Sonner S. Ameloblastoma: a biological profile of 3677 cases. Eur J Cancer B Oral Oncol. 1995;31B(2): 86-99.

4. Hertog D, Bloemena E, Aartman IH, van der Waal, I. Histopathology of ameloblastomas of the Jans: some critical observations based on 40 years single institution experience.Med Oral Patol Oral Cir Bucal. 2012;17(1):e76-82.

5. Junquera L, Ascani G, García-Consuegra L, Vicente JC, Roig P. Ameloblastoma Revisited. Ann Otol Rhinol Laryngol. 2003;112:1034-9.

6. Pinheiro JJV, Freitas VM, Moretti AIS, Jorge AG, Jaeger RG. Local invasiveness of ameloblastoma: Role played by matrix metalloproteinases and proliferative activity. Histopathology. 2004;45:65-72.

7. Philipsen HP, Reichart PA. Unicystic ameloblastoma. A review of 193 cases from the literature. Oral Oncol. 1998;34:317-325

8. Hertog D, van der Waal I. Ameloblastoma of the jaws: A critical reappraisa based on a 40-years single institution experience. Oral Oncology. 2010;46:61-4

9. Barbachan JJD, Rados PV, Filho MS, Quadros OF. Considerações sobre ameloblastomas. R. Fac. Odont.1985;27:13-25.

10. Chidzonga MM, Lopez VM, Alverez AP. Odontogenic tumours: analysis of 148 cases in Zimbabwe. Cent Afr J Med. 1996;42:158-61.

11. Mosqueda-Taylor A, Ledesma-Montes C, Caballero-Sandoval S, PortillaRobertson J, Ruíz-Godoy Rivera LM, Meneses-García A.Odontogenic tumors in Mexico: a collaborative retrospective study of 349 cases. Oral Surg Oral Med Oral Pathol Oral Radiol Endod. 1997;84:672-5
12. Fernandes AM, Duarte ECB, Pimenta FJGS, Souza LN, Santos VR Mesquita RA, Aguiar MCF. Odontogenic tumors: a study of 340 cases in a Brazilian population. J Oral Pathol Med. 2005;34:583-7.

13. Ledesma-Montes C, Mosqueda-Taylor A, Carlos-Bregni R, Romero de León E, Palma-Guzmán JM, Paéz-Valencia C, Meneses-García A Ameloblastomas: a regional Latin-American multicentric study. Oral Diseases. 2007;13:303-7.

14. Adeline VL, Dimba EAO, Wakoli KA, Niiru AK, Awange DO, Onyango JF, Chindia ML. Clinicopathologic Features of Ameloblastoma in Kenya: A 10-Year Audit. The Journal of Craniofacialsurgery. 2008;19: 1589-93.

15. Tawfik MA, Zyada MM. Odontogenic tumors in Dakahlia, Egypt: analysis of 82 cases.Oral Surg Oral Med Oral Pathol Oral Radiol Endod. 2010;109:e67-73.

16. Fregnani ER, da Cruz Perez DE, de Almeida OP, Kowalski LP, Soares FA, de Abreu Alves F.Clinicopathological study and treatment outcomes of 121 cases of ameloblastomas.Int J Oral Maxillofac Surg. 2010;39: $145-9$

17. Fulco GM, Nonaka CFW, Souza LB, Miguel MCC, Pinto LP. Solid ameloblastomas - Retrospective clinical and histopathologic study of 54 cases. Braz J Otorhinolaryngol. 2010;76:172-7.

18. Krishnapillai R, Angadi PV. A clinical, radiographic, and histologic review of 73 cases of ameloblastoma in an Indian population. Quintessense Int 2010:41:e90-e100.

19. Ledesma-Montes C, Ibarra-Villanueva A, Garce's-Ortız M, PortillaRobertson J. Ameloblastoma. Analysis of 338 cases. Med Oral. 2000;5:254-60.

20. Wu PC, Chan KW. A survey of tumors of the jawbones in Hong Kong Chinese: 1963-1982. Br J Oral Maxillofac Surg. 1985;23:92-102.

21. Lu Y, Xuan M, Takata T, Wang C, He Z, Zhou Z, Mock D, Nikai H. Odontogenic tumors: a demographic study of 759 cases in Chinese population. Oral Surg Oral Med Oral Pathol Oral Radiol Endod. 1998;86:707-14.

22. Odukoya O. Odontogenic tumors: analysis of 289 Nigerian cases. J Oral Pathol Med. 1995;24:454-7

23. Daley TD, Wysocki GP, Pringle GA.Relative incidence of odontogenic tumors and oral and jaw cysts in a Canadian population.Oral Surg Ora Med Oral Pathol.1994;77:276-80.

24. IBGE,2008.http://www.ibge.gov.br/home/presidencia/noticias/noticia visualiza.php?id noticia $=737$ 